ISSN: 1410-8917

Jurnal Kimia

Sains \&

Aplikasi
Jurnal Kimia Sains dan Aplikasi Journal of Scientific and Applied Chemistry

Journal homepage: http://ejournal.undip.ac.id/index.php/ksa

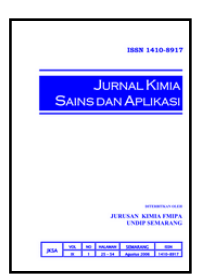

\title{
Aktivitas Antioksidan dan Antibakteri Produk Fermentasi Susu Kedelai dan Whey Tahu menggunakan Bakteri Asam Laktat Komersial
}

\author{
Kunti Nadiyatan S. Muthia ${ }^{a, *}$, Purbowatiningrum Ria Sarjono ${ }^{a}$, Agustina L. N. Aminin ${ }^{a, *}$ \\ a Biochemistry Laboratory, Chemistry Department, Faculty of Sciences and Mathematics, Diponegoro University, Jalan Prof. \\ Soedarto, Tembalang, Semarang 50275 \\ * Corresponding author: agustina.aminin@live.undip.ac.id
}

Article Info

Keywords:

antibacterial, antioxidant, fermentation, tofu Whey, soymilk

Kata kunci:

Antibakteri, Antioksidan, fermentasi, Whey tahu, susu kedelai

\begin{abstract}
The potential of antibacterial and antioxidant activity of fermented soy milk and Whey tofu products by lactic acid bacteria (BAL) has been explored in this study. Fermentation was performed using commercial lactic acid bacteria and incubated at $45^{\circ} \mathrm{C}$. for 7 hours. Antibacterial activity was observed against pathogenic bacteria Escherichia coli, Staphylococcus aureus, and Pseudomonas aeruginosa. Antioxidants were tested using the Folin-Ciocalteu Reagent (FCR) method and scavenging DPPH. The results showed fermented product of soy milk in the form of white lumps with $\mathrm{pH} 5.4$ whereas tofu Whey in the form of liquid mixture and yellow cloudy solid with $\mathrm{pH} 4,7$. The fermentation results do not give inhibition to the growth of pathogenic bacteria. Fermented soy milk and Whey tofu products have a FCR antioxidant capacity of $0.07 \mathrm{mg}$ of gallic acid / gram of sample and $0.04 \mathrm{mg}$ of gallic acid / gram of sample. At $90 \mathrm{ppm}$ each product capable of inhibiting free radical DPPH of $12.53 \%$ and $11.46 \%$ so potentially as an antioxidant.
\end{abstract}

\section{Abstrak}

Potensi aktifitas antibakteri dan antioksidan produk fermentasi susu kedelai dan Whey tahu oleh bakteri asam laktat (BAL) telah dieksplorasi dalam penelitian ini. Fermentasi dilakukan menggunakan bakteri asam laktat komersil dan dinkubasi pada $45^{\circ} \mathrm{C}$ selama 7 jam. Aktifitas antibakteri diamati terhadap bakteri patogen Escherichia coli, Staphylococcus aureus, dan Pseudomonas aeruginosa. Antioksidan diuji dengan metode Folin- Ciocalteu Reagen (FCR) dan peredam DPPH. Hasil penelitian menunjukkan produk fermentasi susu kedelai berupa gumpalan berwarna putih dengan $\mathrm{pH}$ 5,4 sedangkan pada Whey tahu berupa campuran cairan dan padatan berwarna kuning keruh dengan pH 4,7. Hasil fermentasi tidak memberikan penghambatan terhadap pertumbuhan bakteri patogen. Produk fermentasi susu kedelai dan Whey tahu memiliki kapasitas antioksidan FCR sebesar 0,07 mg asam galat/gram sampel dan 0,04 mg asam galat/gram sampel serta pada konsentrasi $90 \mathrm{ppm}$ masing-masing mampu menghambat radikal bebas DPPH sebesar $12,53 \%$ dan $11,46 \%$ sehingga berpotensi sebagai antioksidan.

\section{Pendahuluan}

Whey merupakan produk samping dari proses pembuatan tahu mengandung total protein $0,138 \%$; total pati $0,855 \%$ dan total gula $1,128 \%$ serta isoflavon sebesar $20,77 \%$ relatif terhadap total isoflavon kedelai. Kandungan nutrisi Whey tahu tersebut berpotensi sebagai media pertumbuhan bakteri asam laktat (BAL) seperti Lactobacillus plantarum [1] dan Lactobacillus paracasei [2]. Harmayani dkk. [3] telah memanfaatkan 
Whey tahu untuk media pertumbuhan bakteri Pediococcus acidilactici penghasil bakteriosin.

BAL dalam pertumbuhannya menghasilkan metabolit primer yaitu asam laktat, $\mathrm{CO}_{2}$, diasetil, asetaldehida dan hidrogen peroksida serta metabolit sekunder yaitu bakteriosin yang berpotensi sebagai antibakteri. Adanya asam laktat menyebabkan penurunan $\mathrm{pH}$ sehingga dapat menghambat pertumbuhan bakteri E. coli yang optimum pada $\mathrm{pH}$ 67. Fermentasi oleh BAL juga menghasilkan bakteriosin yaitu bioaktif peptida atau protein yang memiliki aktifitas antimikroba terutama terhadap bakteri gram positif yang berkaitan dengan kerusakan makanan maupun bakteri patogen $[4,5]$. Nurhajati $d k k$. [6] mengemukakan bahwa bakteriosin diproduksi oleh bakteri asam laktat pada awal fase log kemudian mencapai maksimum pada awal fase stasioner dan mengalami penurunan pada akhir fase stasioner hingga fase kematian.

Fermentasi BAL juga mengakibatkan protein kedelai mengalami hidrolisisis menjadi peptida-peptida pendek diantaranya Phe-Asp-His-Val-Glu dan PheAsn- His-Leu-Asp-His yang mampu meredam radikal bebas DPPH [7]. Fermentasi menyebabkan senyawa isoflavon dalam kedelai mengalami transformasi sehingga diperoleh senyawa isoflavon bebas yaitu aglikon berupa genistein, glisitein dan daidzein yang memiliki aktivitas antioksidan yang lebih tinggi daripada bentuk terikatnya [7].

Dalam penelitian ini dilakukan fermentasi susu kedelai dan Whey tahu dengan menggunakan BAL dan penentuan aktivitas antibakteri terhadap bakteri patogen Escherichia coli, Staphylococcus aureus, dan Pseudomonas aeruginosa menggunakan metode difusi cakram. Uji antioksidan dari ekstrak hasil fermentasi susu kedelai dan Whey tahu menggunakan metode Folin-Ciocalteu Reagen (FCR) dan metode peredaman 2,2-diphenyl-1- picrylhydrazyl (DPPH).

\section{Metodologi Penelitian}

Bahan

Filtrat Whey tahu yang telah dipekatkan yang berasal dari pabrik tahu di kelurahan Beji kecamatan Ungaran Timur, susu kedelai "Bukit Sari", laktosa, BAL (Bifidobacterium dan Lactobacillus acidophilus), susu sapi segar yang berasal dari KUD Banyumanik, medium nutrient broth, bacto agar, akuades, ampisilin, tetrasiklin, DPPH, kuersetin, metanol, Folin-ciocalteu, asam galat, $\mathrm{Na} 2 \mathrm{CO} 3, \mathrm{BSA}$, E. coli, S. aereus, P. aeruginosa.

Cara Kerja.

\section{Penyiapan Starter BAL}

Seratus mililiter BAL komersial yang diketahui mengandung Lactobacillus achidophilus dan Bifidobacteria diremajakan terlebih dahulu dalam $1 \mathrm{~L}$ susu sapi steril dan diinkubasi pada suhu $45^{\circ} \mathrm{C}$ [8] selama 4 jam. Sebanyak $10 \mathrm{~mL}$ hasil peremajaan ini ditambahkan ke dalam $200 \mathrm{~mL}$ susu kedelai steril yang telah ditambahkan laktosa sebanyak 0,5\% dan diinkubasi pada suhu $45^{\circ} \mathrm{C}$ selama 4 jam. Hasil inkubasi BAL dalam susu kedelai ini digunakan untuk starter.

\section{Fermentasi Susu Kedelai dan WheyTahu}

Susu kedelai dan Whey tahu steril masing-masing sebanyak $500 \mathrm{~mL}$ ditambahkan dengan laktosa masingmasing sebanyak 2,5 g. Sebanyak $25 \mathrm{~mL}$ starter BAL ditambahkan ke dalam masing- masing susu kedelai dan Whey tahu pada suhu $45^{\circ} \mathrm{C}$. Selanjutnya dilakukan penginkubasian selama 7 jam pada suhu $45^{\circ} \mathrm{C}$. Larutan ekstrak hasil fermentasi diperoleh dengan menyentrifus hasil fermentasi pada 5000rpm selama 30 menit.

\section{Uji Antibakteri Ekstrak Hasil Fermentasi}

Uji antibakteri dilakukan dengan metode difusi cakram dan metode perforasi. Metode difusi cakram yaitu dengan meletakkan cakram kertas yang telah direndam ekstrak hasil fermentasi susu kedelai dan Whey tahu oleh BAL masing-masing selama 15 menit ke dalam cawan petri berisi media NA dan bakteri uji. Metode perforasi yaitu dengan menuangkan $10 \mu \mathrm{L}$ ekstrak hasil fermentasi susu kedelai dan Whey tahu oleh BAL ke lubang sumur (diameter $6 \mathrm{~mm}$ ) dalam cawan petri yang berisi media NA (tebal $5 \mathrm{~mm}$ ) dan bakteri uji [6].

\section{Uji Antioksidan Metode FCR}

Penentuan aktivitas antioksidan metode FCR dilakukan dengan cara 0,2 mL larutan uji direaksikan dengan $15,8 \mathrm{~mL}$ akuades dan $1 \mathrm{~mL}$ reagen FolinCiocalteu, kemudian dikocok dan didiamkan selama 8 menit. Sebanyak $3 \mathrm{~mL}$ larutan $\mathrm{Na}_{2} \mathrm{CO} 320 \%$ dalam aquades ditambahkan ke dalam larutan tersebut kemudian dikocok hingga larutan homogen dan didiamkan selama 30 menit pada suhu kamar. Pengukuran absorbansi larutan dilakukan pada panjang gelombang $765 \mathrm{~nm}$. Standar yang digunakan adalah asam galat

\section{Uji Antioksidan Metode DPPH}

Penentuan aktivitas antioksidan metode DPPH dilakukan dengan cara pembuatan variasi konsentrasi larutan uji 10, 30, 50, 70, dan $90 \mu \mathrm{g} / \mathrm{mL}$. Sebanyak 0,2 mL masing-masing konsentrasi larutan uji ditempatkan dalam botol vial dan ditambahkan dengan 3,8 mL larutan DPPH $50 \mu \mathrm{M}$. Campuran dihomogenkan dan didiamkan selama 30 menit di ruangan gelap. Absorbansi diukur pada panjang gelombang $515 \mathrm{~nm}$. Sebagai standar digunakan kuersetin [9].

\section{Hasil dan Pembahasan}

\section{Fermentasi Susu Kedelai dan WheyTahu}

Hasil pengamatan susu kedelai dan Whey tahu sesudah fermentasi pada susu kedelai berupa padatan berwarna putih dengan $\mathrm{pH}$ 5,4 sedangkan pada Whey tahu berupa campuran cairan dan padatan berwarna kuning keruh dengan $\mathrm{pH}$ 4,7. Menurut Tamime dan Robinson [10] katabolisme dari kultur starter BAL akan menghasilkan asam laktat yang menyebabkan penurunan $\mathrm{pH}$ sehingga terjadi koagulasi. Koagulasi pada susu kedelai menunjukkan tekstur yang kompak 
sedangkan koagulasi pada Whey tahu hanya menunjukkan peningkatan padatan yang bercampur dengan cairan. Hal ini terjadi karena protein susu kedelai lebih banyak daripada Whey tahu.

\section{Uji antibakteri}

Uji antibakteri dengan metode difusi cakram maupun metode perforasi memberikan hasil yang negatif seperti tampak pada tabel 1.

Tabel 1. Uji antibakteri

\begin{tabular}{ccc}
\hline Bakteri Uji & \multicolumn{2}{c}{ Hasil Fermentasi } \\
\cline { 2 - 3 } & Susu kedelai & Whey tahu \\
\hline Escherichia coli & - & - \\
Staphilococcus aureus & - & - \\
P. aeruginosa & - & - \\
\hline
\end{tabular}

Dalam penelitian ini diperoleh hasil ekstrak hasil fermentasi susu kedelai dan Whey tahu dengan pH 5,4 dan $\mathrm{pH}$ 4,7 tidak memberikan penghambatan pertumbuhan E. coli, S. aureus dan P. aeruginosa karena $\mathrm{pH}$ nya masih diatas $\mathrm{pH}$ minimum bakteri tersebut. Jordan dkk. [11] menyatakan bahwa nilai $\mathrm{pH}$ minimum pertumbuhan E. coli adalah 4,3-4,4. S. aureus memiliki pH optimum 6-7 walaupun masih dapat tumbuh pada kisaran $\mathrm{pH}$ 4-10. Menurut Lambert dan Stratford [12] P. aeruginosa memiliki pH minimum 4,6. Staphilococcus aureus dan P. aeruginosa memiliki toleransi terhadap kisaran lingkungan yang luas. P. aeruginosa memiliki keragaman genetik yang tinggi dan memiliki plasmid yang mengkode enzim pada jalur metabolisme khusus, sehingga mampu beradaptasi pada kondisi lingkungan yang ekstrim, seperti pada medium yang cukup asam. S. aureus memiliki plasmid yang membawa gen untuk kekebalan terhadap senyawa antibakteri. pH kurang asam diperkirakan karena waktu fermentasi yang relatif singkat yaitu hanya 7 jam. Pada suhu $45^{\circ} \mathrm{C}$ cepat terjadi penggumpalan dalam waktu 7 jam namun diperkirakan belum mencapai tahap maksimal. Selain itu juga fermentasi oleh BAL pada suhu cukup tinggi yaitu $45^{\circ} \mathrm{C}$ diperkirakan pertumbuhan BAL belum mencapai fase stasioner sehingga belum memproduksi bakteriosin.

\section{Uji Antioksidan Metode FCR}

Kapasitas antioksidan FCR susu kedelai terukur tinggi seperti terlihat dalam gambar 1, karena susu kedelai diketahui merupakan suplemen makanan yang mengandung senyawa fenolik dan isoflavon. Senyawa fenolik dan isoflavon bersifat larut air sehingga mampu terukur dengan baik menggunakan metode FCR.

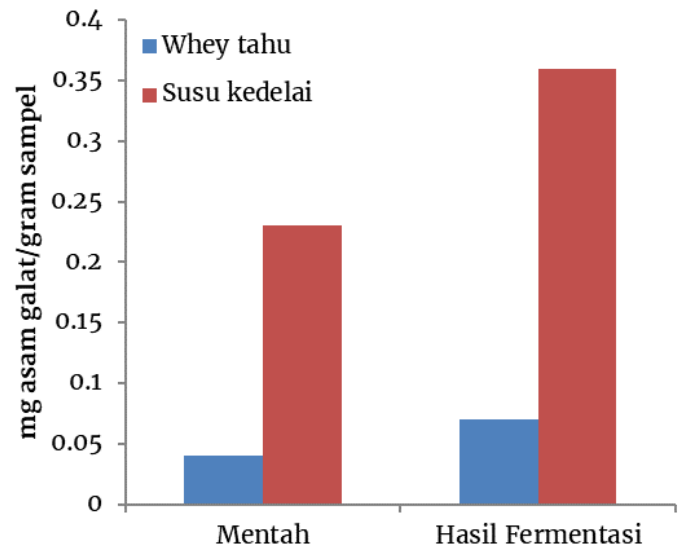

Gambar 1. Kapasitas antioksidan dengan metode FCR

Whey tahu memiliki kapasitas antioksidan 53,49\% dari total kapasitas antioksidan susu kedelai serta ekstrak hasil fermentasi Whey tahu oleh BAL memiliki kapasitas antioksidan 57,14\% dari total kapasitas antioksidan ekstrak hasil fermentasi susu kedelai oleh BAL. Hal ini membuktikan bahwa Whey tahu dan ekstrak hasil fermentasi Whey tahu oleh BAL berpotensi sebagai antioksidan. Whey tahu merupakan produk samping dari pembuatan tahu yang diketahui mengandung isoflavon yaitu anggota flavonoid yang mengandung senyawa polifenol.

\section{Uji Antioksidan metode peredaman DPPH}

Gambar 2 menunjukkan perbandingan persentase inhibisi susu kedelai dan Whey tahu serta ekstrak hasil fermentasi susu kedelai dan Whey tahu oleh BAL. Persentase inhibisi dalam tiap sampel dengan konsentrasi yang sama menunjukkan rata-rata persentase inhibisi Whey tahu lebih besar dibandingkan dengan susu kedelai serta ekstrak hasil fermentasi Whey tahu lebih besar dibandingkan ekstrak hasil fermentasi susu kedelai.

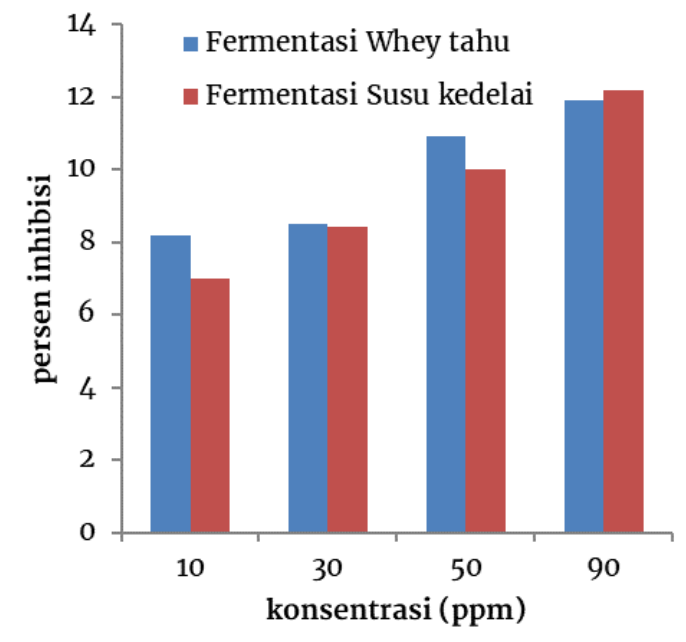

Gambar 1. Kapasitas antioksidan dengan metode peredaman DPPH

Penghambatan radikal DPPH terbesar yaitu pada konsentrasi $90 \mathrm{ppm}$. Susu kedelai dan Whey tahu pada konsentrasi 90 ppm masing-masing mampu 
menghambat radikal bebas DPPH sebesar 23,16\% dan 19,26\%. Ekstrak hasil fermentasi susu kedelai dan Whey tahu pada konsentrasi $90 \mathrm{ppm}$ masing-masing mampu menghambat radikal bebas DPPH sebesar $12,53 \%$ dan $11,46 \%$ sehingga berpotensi sebagai antioksidan

\section{Kesimpulan}

Berdasarkan penelitian yang telah dilakukan dapat disimpulkan bahwa:

1. Fermentasi susu kedelai dan Whey tahu oleh bakteri asam laktat pada suhu $45^{\circ} \mathrm{C}$ selama 7 jam menghasilkan asam-asam organik yang menyebabkan susu kedelai mengalami koagulasi membentuk padatan berwarna putih dan Whey tahu membentuk padatan bercampur cairan berwarna kuning keruh serta ditandai penurunan $\mathrm{pH}$

2. Ekstrak hasil fermentasi susu kedelai dan Whey tahu tidak memberikan terhadap Escherichia coli, Staphylococcus aureus dan Pseudomonas aeruginosa

3. Ekstrak hasil fermentasi susu kedelai dan Whey tahu berpotensi sebagai antioksidan

\section{Daftar Pustaka}

[1] W. Ben Ounis, C. P. Champagne, J. Makhlouf, L. Bazinet, Utilization of tofu whey pre-treated by electromembrane process as a growth medium for Lactobacillus plantarum LB17, Desalination, 229, 1, (2008)

http://dx.doi.org/10.1016/j.desal.2007.08.019

[2] Lê Nguyen Thi, Claude P. Champagne, Byong H. Lee, Jacques Goulet, Growth of Lactobacillus paracasei ssp. paracasei on tofu whey, International Journal of Food Microbiology, 89, 1, (2003) 67-75 http://dx.doi.org/10.1016/S0168-1605(03)00109-0

[3] Eni Harmayani, Endang S. Rahayu, Titiek F. Djaafar, Citra Argaka Sari, Tri Marwati, Pemanfaatan Kultur Pediococcus Acidilactici F-11 Penghasil Bakteriosin Sebagai Penggumpal pada Pembuatan Tahu, Jurnal Pascapanen, 6, 1, (2009) 10-20

[4] J. R. Tagg, A. S. Dajani, L. W. Wannamaker, Bacteriocins of gram-positive bacteria, Bacteriological Reviews, 40, 3, (1976) 722-756

[5] Todd R. Klaenhammer, Bacteriocins of lactic acid bacteria, Biochimie, 70, 3, (1988) 337-349 http://dx.doi.org/10.1016/0300-9084(88)90206-4

[6] Jetty Nurhajati, Chrysanti, Ida Indrawati, Novi Syaftika, Antibacterial Activity of L. bulgaricus and S. thermophilus Soygurt Cultures, 3rd ASEAN Congress of Tropical Medicine and Parasitology, Thailand, (2008).

[7] Issoufou Amadou, Olasunkanmi S. Gbadamosi, Yong Hui Shi, Mohamed T. Kamara, Sun Jin, Guo-Wei Le Le, Identification of Antioxidative Peptides from Lactobacillus plantarum Lp6 Fermented Soybean Protein Meal, Research Journal of Microbiology, 5, 5, (2010) 372-380 http://dx.doi.org/10.3923/jm.2010.372.380

[8] Marman Wahyudi, Proses pembuatan dan analisis mutu yoghurt, Buletin Teknik Pertanian, 11, 1, (2006) 12-16
[9] Philip Molyneux, The use of the stable free radical diphenylpicrylhydrazyl (DPPH) for estimating antioxidant activity, Songklanakarin Journal of Science and Technology, 26, 2, (2004) 211-219

[10] Adnan Y Tamime, Richard Kenneth Robinson, Yoghurt: science and technology, Woodhead Publishing, 1999.

[11] Kieran N. Jordan, Lynn Oxford, Conor P. O'Byrne, Survival of Low-pH Stress by Escherichia coli O157:H7: Correlation between Alterations in the Cell Envelope and Increased Acid Tolerance, Applied and Environmental Microbiology, 65, 7, (1999) 30483055

[12] R. J. Lambert, M. Stratford, Weak-acid preservatives: modelling microbial inhibition and response, Journal of Applied Microbiology, 86, 1, (1999) 157-164 http://dx.doi.org/10.1046/j.13652672.1999.00646.x 